DEMETER Krisztina - LOSONCI Dávid

\title{
A LEAN TUDÁS ÁTADÁSÁNAK GYAKORLATAI MULTINACIONÁLIS HÁLÓZATOKBAN
}

A cikk azt vizsgálja, hogyan áramoltatják a lean menedzsmenttel kapcsolatos tudást a multinacionális vállalatok hálózataikban, azaz a vállalati központ és az egyes leányvállalatok között, illetve a leányvállalatok egymás között. Mivel a lean tudás megosztásával kapcsolatos irodalom még gyerekcipőben jár, kutatási módszerként az esettanulmány-alapú kutatást választották a szerzők. 12 interjú alapján három leányvállalatnál készítettek esettanulmányt. Feltáró kutatásukban 13 tudásmegosztási gyakorlatot azonosítottak. A megosztott tudás jellege, az érintettek és a megosztás gyakorisága alapján osztályozták őket. Kutatásuk rámutat arra, hogy a felső vezetők bevonása a lean tudás megosztásába rendkívül fontos. Ezek a vezetők egyfajta információs ügynök szerepet játszanak (gyüjtik és megosztják a jó gyakorlatokkal kapcsolatos információkat) és iránymutatást adnak a leányvállalati szintü lean erőfeszítéseknek. Kutatásuk további eredménye, hogy a lean fejlődése korántsem egyenes vonalú. A lean hálózati szintü egységes értelmezésének kialakítása alapvető ebben a fejlődési folyamatban. A globális lean tudásközpontnak döntő szerepe van az egységes értelmezési keret kialakításában.*

\section{Kulcsszavak: tudásátadás, lean menedzsment, multinacionális vállalatok}

A lean termelési rendszer napjainkban világszerte felkapott téma. Sok vállalat a legkülönfélébb ágazatokból, a termeléstől a szolgáltatásokig hatalmas erőfeszítéseket tesz a lean menedzsment adaptálása és az abban történő elörelépés érdekében. Elismert kutatók már a '90-es évek végén a termelés és szolgáltatásmenedzsment új paradigmájaként beszéltek a leanről (Schmenner - Swink, 1998). Elmélet és gyakorlat tehát egyaránt alátámasztja, hogy a lean működés az érték-előállítás teljesen újszerủ megközelítése, ami a vállalatok egyre nagyobb részét hatja át, régen túllépve már a termelés határain. Ennek a terjedésnek köszönhető a leannel kapcsolatos új irányok (pl. lean startup, lean six sigma, lean disztribúció, lean logisztika, lean accounting) megjelenése, ezek az irányok azonban még korántsem rendelkeznek olyan kiterjedt akadémiai alappal, mint a lean termelés.

A számos kutatásnak köszönhetően sokat tudunk ma már arról, hogy hogyan épül fel a lean termelési rendszer, beleértve a Toyota rendszerét is (Hines et al., 2004; Kovács, 2004; Kovács - Rendesi, 2014, 2015; Shah - Ward, 2003; Womack - Jones, 2003). Ugyanakkor nagyon keveset tudunk arról, hogy a szervezetek miként szedik össze, fejlesztik, adják át és osztják meg a szükséges lean tudást, hogy lean átalakulásuk elinduljon és fenntartható legyen (Secchi - Camuffo, 2016). Világos, hogy a multinacionális vállalatok előnyt élveznek, mert hálózatukban a tudás megosztására több lehetóség adódik (Argote, 2012). Tekintve a lean termeléssel kapcsolatos tudás fontosságát és a multinacionális vállalatok fejlett tudásmenedzsment-gyakorlatát, meglepő, hogy elenyésző a lean tudásmegosztással foglalkozó empirikus tanulmányok száma (Boyle et al., 2011; Dyer - Nobeoka, 2000; Secchi - Camuffo, 2016). A tudásmegosztásban érintett munkavállalók és a tudásmegosztás technikái, ha elő is kerülnek, akkor is közvetetten, mellékszálként (Inkpen, 2005; Maritan - Brush, 2003).

Esettanulmány-alapú empirikus kutatásunk a lean termelési rendszerrel kapcsolatos tudásmegosztási gyakorlatokat tárja fel három multinacionális vállalat belső hálózatában. A cikk célja továbbá a vállalatoknál zajló tudásátadás körülményeinek és folyamatának vizsgálata. A jelenség megismerése segít a jó gyakorlatok azonosításában, amelyekre a vezetők hatékonyabb lean tudásmegosztási rendszert építhetnek, illetve amelyekkel gyorsabbá tehetik a lean gondolkodás terjesztését. Hangsúlyozzuk, hogy lean tudásátadás alatt nem a tudásátadás leanesítését értjük, hanem azokat a tudásmegosztási gyakorlatokat, amelyeket a vállala- 
tok a lean menedzsmenttel kapcsolatos kiterjedt tudás megosztására használnak. Lehet, hogy tudásmenedzsment szempontjából ezek a gyakorlatok nem újak, ugyanakkor fontosnak tartjuk annak feltárását, hogy melyek a leggyakrabban használt és leginkább hasznosnak tartott tudásátadási mintázatok a lean müködésre törekvő vállalatok életében.

A bevezetést követően összefoglaljuk a szervezetközi tudásátadáshoz és a lean tudásátadáshoz kapcsolódó szakirodalmat. Az empirikus részt az esettanulmányok vállalatainak bemutatása vezeti fel, majd a lean tudásmegosztási gyakorlatok tárgyalása jön. Ezt követi az esetek hasonlóságainak és különbségeinek feltárása és tárgyalása. A cikket a következtetések és a vezetőknek szóló javaslatok zárják.

\section{A szakirodalmi háttér}

Ebben a fejezetben a szervezetek közötti tudásmegosztás témánk szempontjából releváns irodalmát mutatjuk be és külön alfejezetet szentelünk a lean tudásátadás területén rendelkezésre álló irodalom tárgyalásának.

\section{Tudásátadás szervezetek között}

A szervezetközi tudásátadás meghatározásakor mi az alábbi definíciót követjük: ,amikor az egyik szervezetben megszerzett tudás befolyásol egy másikat" (Argote, 2012, p. 148.), vagy más szavakkal, ,amikor a tudás egy másik egység tapasztalatai alapján jön létre" (Argote - Miron-Spektor, 2011, p. 1128.). A nemzetközi üzleti gazdaságtanban számos kutatás foglalkozik a tudásátadással: a mechanizmusok, módszerek mellett, az előnyök, a nehézségek és a kihívások is megjelennek.

A tudás többféleképpen átadható, e mechanizmusok sikere változó (Argote, 2012). A szervezetek között a tudás áramolhat az emberek mozgatásával, ami lehetőséget ad a megfigyelésre és kommunikációra, vagy a tapasztalt egyének átadására a fogadó szervezeteknek, a technológiával, mintapéldákkal, rutinokkal, vagy szociális hálózatokon és szövetségeken keresztül. Az alkalmazottak mozgatása nagyon hatékony megoldás a tudásátadás segítésére (Rosenkopf - Almeida, 2003), és egy leányvállalat stratégiai szerepét jelentősen képes javítani (Vereecke et al., 2006). Az emberek mobilitásának biztosítása még nagy távolságokra is hatékony megoldás lehet (Rosenkopf - Almeida, 2003). Az információtechnológiára építő tudásátadás felfedezést és kiaknázást egyaránt képes támogatni (Kane - Alavi, 2007). Például a nyílt tudástárházak, amelyek mindenkinek elérhetőek, rendezett adatbázisokban állnak rendelkezésre, valamint az elektronikus tanulószobák, amelyek egy-egy projekt résztvevőinek biztosítanak lehetőséget tudásmegosztásra. E módszerek a standard tudás megosztásával és létrehozásával alkalmasak a kiaknázásra, de nem szolgálják a hosszú távú felfedezést/innovációt. Ez utóbbit az e-mail, vagy más egyedi kapcsolatot biztosító rendszerek jobban támogatják, különösen, ha a kapcsolatban állók ismerik a másikat és bíznak egymásban. Jensen és Szulanszki (2007) azt mutatja meg, hogy a mintapéldák (azaz „egy olyan szervezeti gyakorlat, ami létezik, megfigyelhetö, egy vagy több kapcsolódó folyamatból áll, és tudatosan használt a replikációs folyamatban", 1727. old.) szintén alkalmasak a szervezetek közötti tudásátadásra, de a kutatók hangsúlyozzák, hogy a mintapéldának teljes valójában legalább egy helyen léteznie kell, ahova az azt alkalmazni tervezők el tudnak menni, hogy kérdéseiket feltegyék és a valós életben a gyakorlatot megfigyeljék.

Ernst és Kim (2002) Nonaka (1991) tudáskonverziós folyamatát használja, hogy leírja, miként lehet a tudást átadni globális termelési hálózatokban úgy, hogy a fogadó félnél a megfelelő képesség létrejöjjön. Amint magyarázzák, a zászlóshajó szerepét játszó (vezetö) vállalat nemcsak explicit és tacit tudását osztja meg a hálózati partnerekkel, hanem mediátor szerepet is játszik, hogy segítsen a partnernek a tudás konvertálásában (internalizálásában), hogy ezáltal a szükséges képességek kialakuljanak, illetve fejlődjenek.

A szervezetközi tudásmegosztást számos tényező akadályozhatja (Argote - Miron-Spektor, 2011), amelyek közül a legfontosabbak:

- az oksági homály (amikor nem tudjuk, hogy az átadott tudáselemek milyen mértékben járulnak hozzá a fogadó szervezet sikeréhez),

- az alacsony abszorpciós kapacitás (amikor a fogadó fél tudása nem elegendő az átadott tudás megértésére és hasznosítására) (Cohen - Levinthal, 1990), ami föként szakértelem hiányából fakad,

- a kismértékü hasonlóság (technológiai és/vagy földrajzi értelemben), ami a tudás keresését és adaptálását kevésbé eredményessé és drágábbá teszi (Rosenkopf - Almeida, 2003),

- a versenytársi kapcsolat (Dyer - Nobeoka, 2000), és

- a motiváció hiánya mindkét félnél, de főképpen a fogadó szervezetnél.

\section{A lean termeléssel kapcsolatos tudásátadás}

Alig néhány kutatás érhető el a termelésmenedzsmentben, ami a szervezetközi tudásátadással foglalkozik (Lapré - Wassenhove, 2001; Letmathe et al., 2012), és még kevesebbet, ami kifejezetten a lean termeléssel kapcsolatos tudás átadását állítja vizsgálatának középpontjába (Inkpen, 2008; Maritan - Brush, 2003; Staats et al., 2011; Secchi - Camuffo, 2016). 
A releváns munkák két fő vonulatba sorolhatók: az első vonulat a lean tudás külső forrásait elemzi (Boyle et al., 2011; Dyer - Nobeoka, 2000), míg a másik vonulat a belső tudásátadás kérdéseit boncolgatja (Inkpen, 2005; Maritan - Brush, 2003; Secchi - Camuffo, 2016) (1. táblázat).

Boyle és szerzőtársai (2011) kanadai termelővállalatoknál vizsgálták, hogy milyen szerepet játszik a lean transzformációban az, ha a vezetők külső, leannel kapcsolatos információforrásokat használnak. Bár közvetlen kapcsolatot nem találtak, de létezik egy közvetett hatás: a lean információknak kitett vezetők leannel kapcsolatos elkötelezettsége nő és ezáltal végső soron a lean gondolkodás mértéke is magasabb szintet ér el. A kutatók azt a következtetést is levonják, hogy a belső infrastruktúra változásai (folyamatinnováció, új termelési technológia, új információrendszerek, díjak) és a fejlesztő szervezeti klíma (nyitottság, együttmüködés, befogadókészség, adatmegosztás) közvetlenül befolyásolja a vezetők motivációját, hogy a lean információk külső forrásai felé forduljanak, és egyben növeli elkötelezettségüket a lean javítások irányába.

A külső források vizsgálatához sorolható a lean tudás átadásának megjelenése a beszállítófejlesztési programokban. Dyer és Nobeoka (2000) figyelemre méltó leírást ad a Toyota intézményesített tudásmegosztási gyakorlatairól és programjairól a külső hálózatban. Sako (2004) a Toyota, a Nissan és a Honda beszállítófejlesztési programjait mutatja be erős hangsúlyt helyezve a lean szemléletü (vagy folyamatkiválósággal kapcsolatos) javítási erőfeszítésekre. A nemzetközi szakirodalom alapján elmondható, hogy a japán nagyvállalatoknak közvetlen kapcsolatuk van a fö (kulcs) beszállítókkal és irányukba törekednek az intenzív beszállítói együttműködésre. A japán nagyvállalatok rövid és hosszú távú fejlesztési programokat is bevezettek, és jól elkülöníthető csatornákat alakítottak ki a tacit és az explicit tudás átadására. A Toyota különösen eredményes a beszállítói csoportok menedzselésében (pl. Jishuken-csoport). Az egyik legfontosabb tudásátadási mechanizmus az alkalmazottak áthelyezése a beszállítóhoz (közvetlen kapcsolat). MacDuffie és Helper (1997) ezzel kapcsolatban a következőt írja: ,...a lean menedzsment mögött álló tudást nem feltétlenül könnyü a szervezetek között mozgatni. Úgy tünik, hogy föként aktiv megközelitést igényel, ahol a fö alapelveket úgy tanitják, hogy azokat valós kontextusban, adott problémák megoldása közben figyelhetik meg a tanulók" (MacDuffie - Helper 1997, p. 121.).

A belső hálózatra fókuszáló tanulmányok száma még korlátozottabb, különösen, ha az átadási technikákat és érintetteket helyezzük fókuszba. Secchi és Camuffo (2016) több esettanulmányt feldolgozó cikkükben a lean termelési rendszerek terjesztésének folyamatát elemzik. Állításuk szerint a következő feltevés implicit módon áthatja a lean közösséget: ,,... $a$ terjesztés folyamata megtervezett és lineárisan, vízesésszerüen zajlik. A vállalati központ egyelöre definiált, kodifikált lean termelési rendszert közvetít az üzemek felé elöre rögzitett lépésekkel haladva. E lépések közé tartozik jellemzöen a vállalati kommunikáció, a felsö és középvezetők képzése, belsö és/vagy külső tanácsadás stb." (Secchi - Camuffo, 2016, p. 63.). E leegyszerủsített megközelítéssel szemben a szerzők arra a megállapításra jutnak, hogy a terjesztési folyamatok hatékonysága

1. negatív kapcsolatban áll a lean tudás kodifikációs szintjével (azaz minél inkább leírt, standardizált a tudás, annál kevésbé terjed),

2. pozitív kapcsolatban van a lean fejlesztéssel megcélzott üzem autonómiájával (azaz minél nagyobb az üzem döntéseinek szabadságfoka, annál jobb a lean befogadása),

3. az alkalmazottak közvetlen bevonásának szintjével (contextual ambidexterity) egy irányban alakul (azaz minél inkább beépülnek a lean gyakorlatok és maga a gondolkodás az egyes emberek szintjén, végzik az egyének a lean fejlesztéseket mindennapi munkájuk mellett, annál sikeresebb a lean tudás terjedése).

Inkpen (2005) a General Motors (GM) és a GM és a Toyota közös leányvállalata (NUMMI) között megvalósuló tudásmegosztást vizsgálta közel két évtized alapján. A két évtized alatt a GM oldaláról folyamatosan változott a kapcsolat intenzitása a NUMMI-val a lean tudásátadásban. Ez érintette a szervezeti formát, a bevont munkavállalók körét és a technikákat is. Nagy lökést és kiterjedt eszközrendszert akkor kapott ez az együttmüködés, amikor a GM CEO-ja egy, a programban korábban részt vett vezető lett. Éppen a hosszú időtáv feldolgozása miatt azonban számos részlet nem jelenik meg. A szerző egyértelmüen felhívja a figyelmet arra, hogy a GM a megtanultakat elsősorban - a tengerentúli - zöldmezős beruházásoknál tudta kamatoztatni.

Maritan és Brush (2003) a lean termeléssel kapcsolatos tudásátadást (megfogalmazásukban flow manufacturing) egy észak-amerikai diverzifikált termelővállalat négy leányánál vizsgálták. A leannel kapcsolatos tudás transzfere közvetlenül megjelenik a lean termelés bevezetésének folyamatában. A tudástranszfer legtöbbször a képzésre kihegyezve kerül elö, amiben a központi tanácsadó csapat meghatározó. A központi tanácsadó csapat mellett az egyes egységek is felállítottak lean csapatokat. A központi tanácsadó mellett a legsikeresebb lean transzformációt végrehajtó egység, 
az ún. mintaegység tudásának volt még kiemelkedő hatása a belső hálózat tudástőkéjére. A mintaegység nemcsak a többi egységbe transzferál tudást (pl. szakértők és vezetők átadásával), hanem a központ irányába is. A mintaegység melletti három egység nem kapcsolódik be a tudás átadásába a küldő oldalon.

A lean tudásátadással kapcsolatos irodalmat az 1 . táblázat foglalja össze. Az irodalom áttekintése alapján levonhatjuk a következtetést, hogy a releváns tanulmányok száma egyelőre korlátozott. Hiányérzetet kelthet, hogy a szervezetközi tudásmegosztás szakirodalmi hátteréhez képest kevés figyelmet kap a lean irodalomban akár a mechanizmusok, akár az akadályozó tényezők kutatása. Keveset tudunk továbbá arról, hogy a multinacionális vállalatok miként fejlesztik és osztják meg a tudást belső hálózataikban. E vállalati körre fókuszálva a korábbi tanulmányok csak részlegesen foglalkoznak a tudásátadási mechanizmusokkal, amelyek a tacit és az explicit tudás átadását támogatják.

A következő kérdések azonban még megválaszolatlanok, ezért ezekkel foglalkozunk a cikk hátralévő részében:

1. Melyek a tipikus tudásátadási gyakorlatok a multinacionális vállalatok belső hálózataiban a lean tudás megosztására?

2. Hogyan támogatja a központi lean tudásközpont a lean tudás átadását?

\section{A lean tudásátadás irodalmának fớ megállapításai}

\begin{tabular}{|c|c|c|c|c|c|}
\hline & \multicolumn{2}{|c|}{ Külsó hálózat } & \multicolumn{3}{|c|}{ Belsó hálózat } \\
\hline $\begin{array}{l}\text { Kutatás } \\
\text { fókusza }\end{array}$ & $\begin{array}{l}\text { Külső információ- } \\
\text { források hatása }\end{array}$ & Beszállítófejlesztés & Lean terjesztés & $\begin{array}{l}\text { Tanulás stratégiai } \\
\text { szövetségben - GM } \\
\text { és NUMMI }\end{array}$ & $\begin{array}{l}\text { Észak-amerikai ter- } \\
\text { melővállalat lean } \\
\text { bevezetése négy leány- } \\
\text { vállalatnál }\end{array}$ \\
\hline Szerzők & Boyle et al. (2011) & $\begin{array}{l}\text { Dyer és Nobeoka } \\
\text { (2000), MacDuffie } \\
\text { és Helper (1997), } \\
\text { Sako (2004) }\end{array}$ & $\begin{array}{l}\text { Secchi és Camuffo } \\
\text { (2016) }\end{array}$ & Inkpen (2008) & $\begin{array}{l}\text { Maritan és Brush } \\
\text { (2003) }\end{array}$ \\
\hline $\begin{array}{l}\text { Mód- } \\
\text { szertan }\end{array}$ & kérdőív & esettanulmány & hét esettanulmány & esettanulmány & $\begin{array}{l}\text { beágyazott esettanul- } \\
\text { mány }\end{array}$ \\
\hline Ország & Kanada & USA, Japán & Olaszország & USA (központ) & USA \\
\hline $\begin{array}{l}\text { Vizsgálat } \\
\text { tárgya, } \\
\text { módja }\end{array}$ & gyártók (N=109) & $\begin{array}{l}\text { interjú, vállalat- } \\
\text { látogatás; Toyota, } \\
\text { Honda, Nissan és } \\
\text { beszállítóik }\end{array}$ & $\begin{array}{l}\text { interjú, vállalatlá- } \\
\text { togatás }\end{array}$ & $\begin{array}{l}\text { személyes és telefo- } \\
\text { nos interjú, látoga- } \\
\text { tások }\end{array}$ & $\begin{array}{l}\text { félig strukturált interjú } \\
\text { különböző munkavál- } \\
\text { lalókkal }\end{array}$ \\
\hline $\begin{array}{l}\text { Gyakor- } \\
\text { latok }\end{array}$ & $\begin{array}{l}\text { - konferencia } \\
\text { - tréning szekciók } \\
\text { - jutalomút más } \\
\text { üzemekbe (mul- } \\
\text { tinacionális } \\
\text { vállalaton belül, } \\
\text { workshopok } \\
\text { szervezése) }\end{array}$ & $\begin{array}{l}\text { - jishuken csoport } \\
\text { - közvetlen kapcso- } \\
\text { latok } \\
\text { - beszállítói társaság } \\
\text { - üzemszintú támo- } \\
\text { gatás }\end{array}$ & $\begin{array}{l}\text { - lean bevezetési } \\
\text { modell (alapelv } \\
\text { alapú vagy rész- } \\
\text { letes leírás) } \\
\text { - kézikönyvek } \\
\text { - lean gyakorlatok } \\
\text { alkalmazási sor- } \\
\text { rendje } \\
\text { - audit } \\
\text { - tréning } \\
\end{array}$ & $\begin{array}{l}\text { - kiküldetés } \\
\text { - tanulócsoport } \\
\text { - rövid látogatás } \\
\text { - vezető áthelyezése } \\
\text { - workshop } \\
\text { - tanácsadó csapat }\end{array}$ & $\begin{array}{l}\text { - belső tanácsadó } \\
\text { csapat } \\
\text { - szakértók és vezető } \\
\text { átvétele másik egy- } \\
\text { ségbe }\end{array}$ \\
\hline $\begin{array}{l}\text { Fó meg- } \\
\text { állapítá- } \\
\text { sok }\end{array}$ & $\begin{array}{l}\text { - a lean gondolko- } \\
\text { dást nem befolyá- } \\
\text { solja közvetlenül, } \\
\text { hogy a vezetés } \\
\text { külsó forrásokkal } \\
\text { találkozik }\end{array}$ & \begin{tabular}{|c|} 
- az explicit és a ta- \\
cit tudásmegosztás \\
csatornái támogat- \\
ják a rövid és hosz- \\
szú távú fejlesztési \\
törekvéseket \\
- alkalmazottak \\
közvetlen bevonása
\end{tabular} & $\begin{array}{l}\text { - a lean terjedési } \\
\text { folyamat függ a } \\
\text { lean tudás ko- } \\
\text { difikáltságának } \\
\text { szintjétól, az adott } \\
\text { gyár autonómiájá- } \\
\text { tól és az alkalma- } \\
\text { zottak lean bevo- } \\
\text { násának szintjétól } \\
\text { (contextual ambi- } \\
\text { dexterity) }\end{array}$ & $\begin{array}{l}\text { - látványos eredmé- } \\
\text { nyeket a zöldmezós } \\
\text { beruházásoknál } \\
\text { értek el } \\
\text { - jelentôs a szociális } \\
\text { interakciók szerepe } \\
\text { - nagy lendületet } \\
\text { akkor kapott a } \\
\text { GM-ben a prog- } \\
\text { ram, amikor a szö- } \\
\text { vetségben érintett } \\
\text { lett a CEO }\end{array}$ & $\begin{array}{l}\text { - a központi egység } \\
\text { mellett egy-egy } \\
\text { leányvállalat is ki- } \\
\text { emelten alakíthatja a } \\
\text { lean tudást } \\
\text { - sikeres lean egység } \\
\text { lean vezetójének } \\
\text { átvitele másik egy- } \\
\text { ség lean csoportjába } \\
\text { jelentős hatású }\end{array}$ \\
\hline
\end{tabular}




\section{A kutatás módszertana}

Mivel a kutatott területen egyelöre nincs elegendő tudás, ezért a felfedező kutatáshoz az esettanulmány módszerét hívtuk segítségül (Yin, 2003). Mintaválasztásunk elsődleges szempontja a hozzáférhetőség volt. Kapcsolatrendszerünkben olyan vállalatokat kerestünk, amelyek nyitottak a kutatásra, és amelyek a lean alkalmazásában már számottevő tapasztalattal rendelkeznek. A három kiválasztott leányvállalat anyacége más-más országban található (Németország, Mexikó és Dánia). A kutatás eddigi fázisában 12 interjút készítettünk, mindegyiket legalább egy óra terjedelemben. Az interjúkhoz előre elkészített kérdéssorozatot használtunk, amelyet igény esetén az interjúalanyokkal elöre is megosztottunk. Szükség esetén a kérdéssortól eltértünk.

Az interjúkban rákérdeztünk a lean menedzsment cégen belüli történetére és szervezeti hátterére. Feltérképeztük a tudásátadási gyakorlatokat, melyek segítségével a leányvállalatok a multinacionális hálózat más leányvállalataitól, illetve a vállalati központtól tudáshoz jutnak, valamint saját tudásukat másokkal megosztják. Az interjúalanyok a következő pozíciókból kerültek ki: lean vezető, lean koordinátor, lean coach, termelésvezető, értékáram vezető, beszerzésvezető.

\section{A vállalati esetek leírása}

Ebben a fejezetben bemutatjuk a vizsgált vállalatok hátterét és lean gyakorlatait. A gyakorlatokat a cikk végén Mellékletben is összefoglaljuk. A vállalatokat nevük helyett a cikkben származásukkal azonosítjuk.

\section{A német leányvállalat}

A német multinacionális vállalat a Bosch-csoport, amelynek négy üzletága van: a) a mobilitási megoldások, b) az ipari technológia, c) a fogyasztói termékek és d) az energia- és építési technológia. A cégnek 440 leányvállalata és 290.000 alkalmazottja van világszerte. A magyar leányvállalatot, a Robert Bosch Power Tool Kft-t, ami a fogyasztói termékek szegmensébe tartozik, 2001-ben alapították, 2015-ben mintegy 1.700 alkalmazottja volt.

A multinacionális vállalat 2003-ban kezdett foglalkozni a leannel, így a leányvállalat már az alapításától fogva a lean szemlélet elkötelezett követője. Átfogóan, a multinacionális cég a lean adaptációját világszerte a lean eszközök alkalmazásával kezdte. Mára kialakított egy lean szellemiségü termelési rendszert a Toyota termelési rendszert mintaként használva, amit kiegészített egy nagyon kifinomult auditrendszerrel, hogy az alkalmazás mértékét a leányvállalatoknál mérni tudja. 2009 környékén a lean adaptálásában volt egy jelentő- sebb szemléletváltás: ráébredtek, hogy nem célszerű a lean módszertant csak azért alkalmazni, hogy legyen, így onnantól egy célorientált megközelítésre váltottak. Ennek megfelelően az új auditrendszer már nemcsak az egyes lean eszközök (elvek) alkalmazásának szintjét méri, hanem annak hatását is a stratégiai célokra. Üzletági szinten a leányvállalatnak a legjobb a teljesítménye, de úgy érzékelik, hogy a vállalat más üzletágaiban felhalmozott tudásból (pl. mobilitási megoldások üzletágban) még tanulhatnak.

A leányvállalat értékáramok mentén szervezi tevékenységét, azaz nemcsak a gyártás, hanem minden más funkcionális egység képviselői is értékáramokhoz vannak rendelve. A leányvállalatnál kezdetben négy értékáram működött, amelyek inkább viszonylag változatos termékportfólióval rendelkező termékcsoportoknak voltak tekinthetők. Az értékáramokat 2016 elején további kisebb, homogénebb értékáramokra bontották.

A multinacionális vállalat lean szervezete kiterjedt. Mintegy 30 ember dolgozik a négy üzletágat kiszolgáló globális lean csapatban, de van üzletági szintü lean csapat is. Helyileg az esetvállalatnál 8 fó dolgozik a lean csapatban és további 6 fö közvetlenül az értékáramokhoz rendelve.

A globális és üzletági szintű lean szakértők rendszerint mély elözetes lean ismeretekkel rendelkeznek, amelyekre a leányvállalatoknál tettek szert. A globális és üzletági szintü csapatok elektronikusan elérhető kézikönyveket készítenek, eseményeket és auditokat szerveznek, és támogatják a leányvállalatok lean erőfeszítéseit megfelelő információkkal és szakértelemmel szolgálva, igény szerint. Rendszeresen látogatják a leányvállalatokat, és ellenőrzik, milyen hatással járnak tanácsaik. Ugyancsak aktívan részt vesznek a sokszor hónapokig tartó mintaprojektekben, amelyek később benchmarkingként szolgálnak más leányvállalatoktól érkezők számára. A mentorálási tevékenység mellett coaching típusú feladatokat is ellát a központi csapat. Bár megfogalmazhatnak akár ambiciózus elvárásokat is, nem irányítják a gyárakat, a gyárak haladása a lean termelési rendszerben döntően a gyárigazgatók ambícióitól függ.

A lean kézikönyveken túl a vállalati intraneten elérhetők az egyes leányvállalatoknál végrehajtott, dokumentált lean projektek. Ezeket a projektleírásokat főként ötletgenerálásra és/vagy a releváns kontaktszemélyek megtalálására használják.

Vannak rendszeres szóbeli tudásmegosztási lehetőségek is. A globális lean csoport kétévente globális lean konferenciát rendez gyárigazgatóknak (páros évek). A konferenciákon elhangzó prezentációkat körültekintően választják ki a globális lean csoport szakértői, és a legjobbakat jutalmazzák. Egy másik találkozót, a termelési konferenciát, is két évente szerveznek globális szinten (páratlan évek). E konferencia keretében kis- 
csoportos gyárlátogatásokat szerveznek a vendéglátó ország gyáraiba, tudásmegosztási célzattal. Ennek keretében rendszerint elökerülnek a lean fejlesztések is. A gyárigazgatóknak negyedéves találkozói is vannak.

A leányvállalatoknál dolgozó lean koordinátoroknak és szakértőknek üzletági szintủ éves találkozókat szerveznek, amelyeket rendszerint egy-egy témára füznek fel. A gyárigazgatók és a lean szakértők rengeteg információt szednek össze e rendszeres eseményeken. Néha további információkhoz is hozzájutnak lean auditokon, mivel az adott leányvállalatot két másik leányvállalat egy-egy embere auditálja.

Sok tevékenység igény szerint zajlik. A releváns információk alapján a szakértőket, mérnököket, sőt esetenként operátorokat más leányvállalatokhoz küldik a jó megoldások tanulmányozása céljából, amelyeket később odahaza be tudnak vezetni. Ezen utazások részeseit előrehaladásuk és lean javítás iránti elkötelezettségük alapján választják ki. A lean szakértők saját területükön üzletágon belül időnként más gyárakban tartanak tréninget vagy workshopot (akár adott eszköz bevezetésében is közremüködve), az adott témában certifikált trénernek ez a fajta tudásmegosztás kifejezetten feladata. Természetesen vannak bejövő benchmarking látogatások is, havonta legalább egy, amelyeket a helyi lean csoport koordinál. A vállalat kétéves junior menedzsmentprogramot müködtet, melynek résztvevői több hónapot töltenek más leányvállalatoknál egy dedikált feladat megvalósításával. Előfordul, hogy a junior program keretében a lean terület is bekapcsolódik.

\section{A mexikói leányvállalat}

A vizsgált gyár 1993-as alapítása után kétszeri tulajdonosváltással 2007-ben lett a mexikói konszern, a Nemak leányvállalata. A mexikói multinacionális vállalat világszerte 35 gyártó leányvállalattal és mintegy 21.000 alkalmazottal müködik. Autóiparnak fejlesztenek és gyártanak alumínium alkatrészeket. A kutatásba bevont leányvállalat kb. 1.200 alkalmazottat foglalkoztat. Sok leányvállalatnál már a ' 90 -es években voltak törekvések a lean bevezetésére, de ezek az eröfeszítések megmaradtak a leányvállalatok szintjén. A jelenlegi tulajdonos általi felvásárlás után néhány évvel fogalmazódott meg a szándék a lean globális szinten történő egységes alkalmazására.

A lean eszközök standardizálására 2014-ben indítottak programot. A multinacionális vállalat leányvállalatainak féléves hullámokban kell új és új standard lean eszközöket bevezetniük, illetve, amennyiben már valamilyen változat müködött, a globális standardnak megfelelően alakítaniuk. A látogatás időpontjáig két lean eszköz, az 5S és a standard munka került napirendre és az értékáram feltérképezés volt a következő eszköz a sorban.
Mind globális, mind regionális (leányvállalatunk esetében európai) szinten egy-egy lean vezető van. Az európai lean vezető az egyik leányvállalat lean vezetője. Európai szinten elkülönített lean szervezet nincsen, a tagokból szerveződő hálózatról beszélhetünk. A leányvállalat lean csoportja 7 tagot számlál és további 3 diák segíti munkájukat. A többi leányvállalattal összevetve a magyar cég a legjobb a TPM-ben (total productive maintenance). A többi eszközt tekintve az átlagmezőnyben helyezkedik el. Helyi szinten nagyon eredményesnek látják a dolgozói javaslattételi rendszert, évente közel ezerötszáz dolgozói ötletet adnak be. A tudásmegosztás elsősorban regionális szinten zajlik.

A multinacionális vállalat online rendszerében megtalálhatók és elérhetők a különböző európai gyáraknál megvalósított lean fejlesztések. Ezt az online adatbázist 2015 vége felé indították. A helyi lean csapat körültekintően tanulmányozza a feltöltött információkat és képeket, néhány relevánsat közülük magyarra is lefordít, hogy a gyári lean TV-n sugározzák, valamint elküldjék a területi vezetőknek a gyárban. A leírásokat jövőbeli projektekhez inspirációs céllal is használják.

A lean szakértők évente háromszor két-három napos találkozón vesznek részt valamelyik gyárban. Ezen idő alatt gyárat látogatnak, megvitatják a látogatás során fellelt javítási lehetőségeket. Az európai lean vezető minden gyárat legalább évente egyszer meglátogat. A lean szakértőknek havi videókonferenciáik vannak, amelyeket az európai lean vezető tart, miután az aktuális lean eszköz bevezetéséről szóló önértékelő jelentéseket az európai központba beküldték. Ezekben a jelentésekben egy elvárt szintet kell elérni, ami az utóbbi időben a leányvállalatokat további lean szakértők alkalmazására ösztönzi. Az európai vezető komoly elvárásokat fogalmaz meg a helyi lean vezetők irányába. A leányvállalatoknál önértékelés alapú éves audit van, amit külső szakértő (az európai lean vezető által kijelölt, másik leányvállalatnál dolgozó lean szakértő) ellenőriz. Az év végi önértékelés alapján a gyárnak a következő évben külső szakértő által is jóváhagyott három projektet kell indítania, amelyek eredményeit a külső szakértő év végén ellenőrzi. Ezekről a projektekről a gyári vezetésnek kell döntenie. A döntésnél a gyári vezetés egyéb üzleti megfontolásokat is figyelembe vesz.

Más gyári területek európai szakértői is legalább éves rendszerességgel találkoznak egymással a tapasztalatok megosztása érdekében. Elméletileg az alkalmazottak más gyárak kaizen eseményein is részt vehetnének, de nyelvi okokból az esetvállalat ezt a lehetőséget még nem aknázta ki.

Egy újfajta kezdeményezés a tudásmegosztó csapatok kialakítása, melynek keretében az egyes termelési 
lépések szakértői a különböző gyárakból kéthavonta összejönnek és egy gyárat részletesen kiértékelnek. Itt elsősorban technológiai kérdések állnak a középpontban. Az egyes gyárak lean érettségétöl függően a leanes eszközök is napirendre kerülhetnek.

\section{A dán leányvállalat}

A dán multinacionális vállalat, a Grundfos a kisgépgyártó szegmensben múködik. A cégnek 16 gyára van világszerte és több, mint 50 értékesítési egysége, öszszesen közel 20.000 fővel. A Grundfos Magyarország Kft. négy üzemmel és egy logisztikai központtal müködik, kb. 2.000 alkalmazottat foglalkoztat.

A lean termelés adaptálásával kapcsolatos tudatos erőfeszítések az esetvállalatnál 2010 körül kezdődtek. A multinacionális vállalati központ stratégiai térképén nem tüntette fel a lean kifejezést, inkább üzemi kiválóságként hivatkozik rá. A bevezetés első körében az esetvállalat a lean eszközök bevezetésére fókuszált. Az üzemi kiválóság kereteit központilag alakították ki, ám a gyáraknak ezt a keretet használva maguknak kellett célkitűzéseket meghatározniuk. 2014-ben a dán leányvállalat tanácsára és segítségével egy tanácsadó céggel kötöttek szerződést, melynek keretében a tanácsadók lean coach-okat biztosítottak a négy gyár egyikében dolgozó vezetőknek a vezetői elkötelezettség és tudás fejlesztése érdekében. Kutatásunkat ebben a gyáregységben végeztük.

A vállalati központban van egy folyamatmenedzsmenttel foglalkozó csoport, amelyben néhány ember kifejezetten az üzemi kiválóságért felel. Magyarországon négyen dolgoznak a lean csapatban. Ez a négy szakember helyi szinten egy központi szolgáltatóként müködik, minden gyárat igény szerint támogatnak. Intenzív tudásmegosztás regionális szinten van (amerikai, európai, ázsiai régió). A legintenzívebb tudásmegosztás a dán leányvállalattal zajlik, mivel ez a két leányvállalat jár a lean terén a legelöl.

Globális szinten oktatási anyagokat alakítottak ki a különböző vezetői szintekre. Munkamegosztási célzattal globális szintü tematikus (lean eszköz) szakértőket neveztek ki az egyes gyárak lean szakértöi közül. Ök a felelösek más leányvállalatok vezetőinek adott lean eszközzel kapcsolatos oktatásért. A multinacionális cégnél intraneten megosztják a projektleírásokat és a tanulságokat (bár ezeket ritkán, leginkább kontaktpontként használják).

A lean csoportok vezetői globálisan évente egyszer találkoznak. E találkozó keretében a lean stratégiai kérdések, az előrehaladás, a problémák és a jó megoldások kerülnek elő. Az európai lean vezetők évente általában kétszer találkoznak egy gyárlátogatás keretében. A globális találkozóhoz hasonlóan itt is előkerül a lean stratégia, de ezen túl a háromnapos esemény a felkeresett gyár fejlesztését célzó problémamegoldó workshopként is funkcionál. A workshop eredménye egy fejlesztési terv, amit a helyieknek kell végrehajtaniuk. A helyi vezetőnek lehetősége van néhány hetet más gyárakban eltölteni, a terv végrehajtását támogató tudást így tudja elmélyíteni. A lean szakértőknek vannak negyedéves videótalálkozóik az előrehaladásról és végrehajtott projektekről. Bár ezek leginkább az információk megosztásáról szólnak.

A lean rendszerrel támogatható stratégiai célokat a lean csoportok vezetöi és a központi (lean) egység határozza meg, amelyet aztán a legfelső, vállalatcsoport szintủ vezetés területért felelős vezetője hagy jóvá. Ezeket az irányokat és a célokat a helyiek bontják le, elég nagy szabadság mellett. A bevezetés kulcsmutatóit a helyi vezetés évente határozza meg és önértékeli egy központi iránymutatás szerint készült audit alapján. Az audit eredményeit helyi szinten megbeszélik, a felelős vezetőknek is továbbítják, de tényleges visszacsatolás még nem alakult ki.

Jó a kooperáció a dán leányvállalattal. A tanácsadó cég levonulása után a dán vezetők vették át a coach szerepet. Dániában egy nagy projektet követően két évig foglalkoztak a fenntartással, ennyi idő alatt vált vezetői rutinná a szemlélet. Így most a dán vezetők tanítják az eszközöket és kihívások elé állítják (coacholják) az esetvállalat vezetőit. A helyi lean szakértők is látogathatják a dán gyárakat.

\section{Az esettanulmányok értékelése}

Az esetvállalatok lean történetét nézve, mindegyik a lean eszközök bevezetésével kezdte, de később irányt váltottak. Néhány évvel a kezdés után a német leányvállalat a lean stratégiai célú használata felé fordult, a lean korábbi öncélú alkalmazását felváltva. Az első évek öncélú alkalmazásának eredményeként kialakult egy magas szintü lean tudás, amely ma lehetővé teszi, hogy a gyárszintű üzleti céloknak, illetve értékáramszintü céloknak alárendelve határozzanak meg lean szellemiségü változtatásokat. A mexikói leányvállalat helyi szinten önállóan indult el a lean termeléssel, több eszközben és elvben a gyár egyes területein eredményeket is elért. Nem vált azonban a gyárban a napi termelési rutin részévé a lean. A gyár most a klasszikus lean eszközök globális szintű standardizálásával a korábbihoz képest új logika mentén építkezik. A dán vállalat magyar gyára az eszközorientált megközelítés fenntarthatóságának nehézségei és a dán leányvállalat tapasztalatai alapján felismerte a vezetôi elkötelezettség erősítésének fontosságát, és a lean kultúra kialakítása irányába mozdult lean coachok és lean koordinátorok bevonásával. Bár a lean szakirodalom a lean termelési rendszer szervezeten belüli fejlődését lineá- 
risként írja le, amint ezt Secchi és Camuffo (2016) is említette és kifogásolta, a mi példáink sem támasztják alá a lineáris fejlődést. A lineáris fejlődést más példák (Scherrer-Rathje et al., 2009) is megkérdőjelezik. Mindegyik esetvállalatunknál jelentős irányváltások történtek a célokban, az alkalmazott eszközökben és alapelvekben. Hasonló jelentős változások voltak esetenként a központ és a leányvállalat kapcsolatában, a lean csoportok szervezeten belüli szerepfelfogásában, illetve a leányvállalat üzletágon belüli helyzete is sokat módosulhatott.

A leányvállalatok történetét tudásmenedzsment szemszögből nézve, a lean eszközök alkalmazásával való kezdés szükségesnek tűnik ahhoz, hogy egy releváns szintủ abszorpciós kapacitás (Cohen - Levinthal, 1990) épüljön ki, ami alapként, platformként szolgál a további tanuláshoz (Ernst - Kim, 2002). Az abszorpciós kapacitás kiépítése egyedül, kizárólag a helyi saját erőforrásokra építő megközelítésben nagyon nehéz. Az esetek közül leginkább a dán leányvállalat szenved a központi iránymutatás hiánya miatt. Bármilyen motiváltak is, szükségük lehet erőteljesebb orientációra. Náluk azonban egy sajátos megoldás bontakozik ki. Az elmúlt időszakban elkezdett változások az erőteljes orientáció irányába mutatnak, pl. dán ,,javaslatra” átfogó lean kultúraváltási program indult a helyi gyárakban, önértékelö auditrendszert alakítottak ki. A dán vállalat magyar egysége a központi lean csapat mellett erőteljesen követi a dán egységet, amely a Maritan és Brush (2003) által vázolt mintaegység szerepét tölti be a belső hálózatban. Ez a magyar üzem pedig tudatosan készül a többi magyar üzem mintaegységévé válni. Összességében, meglátásunk szerint, a központi lean egység fontosnak tünik, különösen a fejlődés kezdetén. Ebben a kérdésben eredményeink némileg ellentmondanak Secchi és Camuffo (2016) megállapításának, miszerint a decentralizált fejlődés az előnyös. Szerintünk ez a megállapítás csak azokra a leányvállalatokra igaz, amelyek már elegendő tudással és megfelelő képességekkel rendelkeznek a lean terén. A fejlödés első szakaszában a globális nyomás és orientáció hasznos a szükséges abszorpciós kapacitás kiépítése és a közös nyelv kialakítása érdekében. Ezt ismerhették fel a mexikói leányvállalatnál, amely a globális standardizáció teljes átvételével feladta az önálló megközelítést, illetve ez a szemléletmód hozott eredményeket a német leányvállalatnál, amely erős alapokra építve, tudatos központi irányváltással és proaktív helyi vezetéssel tudott a lean kultúra irányába fejlődni. Később a központi egység szerepe megváltozhat és sokkal inkább a globális események szervezőjévé válhat, információkkal és tapasztalatokkal támogatva a leányvállalatokat. Sőt, az is előfordulhat, hogy differenciál a lean adaptálásában: az arra nyitott egységekben a világszintủ (vál- lalatcsoport-szintü) újdonságokkal kísérletezhetnek, irányt mutatva az üzletágban.

A tudásátadásnak sok különböző csatornáját sikerült feltérképeznünk. Néhány közülük az explicit tudásmegosztásnak teremt platformot, míg mások a tacit tudás áramlását szolgálják. Az explicit tudásmegosztás a három cégnél nagyon hasonló. Mindegyik esetben az intranetet használják a lean eszközleírások, kézikönyvek, oktatási anyagok, projektleírások és értékelések megosztására. Az explicit tudás megosztása a folyamat elején az abszorpciós kapacitás kiépítésének fontos eszköze. Szervezeti szinten szerzett tapasztalataink egybecsengenek Lethmathe és szerzőtársai (2012) véleményével, akik az egyéni tanulás szintjét vizsgálva arra jutottak, hogy termelési feladatoknál az explicit tudásátadás a tudásátadás többi formájához képest eredményesebb.

Sokkal több különbség van a tudásmegosztás más formái terén, különösképpen a rendszeres tudásmegosztási gyakorlatokban. A német esetvállalatnál a gyárigazgató kulcsszerepet tölt be a rendszeres tudásmegosztásban. Találkozóik kifinomult információmegosztási mechanizmusként müködnek, ahol explicit és tacit tudáselemeket is megosztanak egymással. Hasznos információkat és tapasztalatokat szereznek ezeken a találkozókon, megismerkedve jó gyakorlatokkal prezentációk formájában és gyárlátogatások alkalmával. Így biztosabban tudnak dönteni arról, hogy hova küldjék alkalmazottaikat tapasztalatszerzésre, vagy jártasságuk növelése érdekében. A gyárigazgatók új ismeretei és tapasztalatai utat mutathatnak a leányvállalat további fejlődéséhez. Ezért a német leányvállalatnál, ahol a gyárigazgatók kulcsszerepet játszanak, a felülről lefelé való megközelítés sokkal erősebb, mint a másik két vállalatnál. Ugyancsak érdemes hangsúlyozni, hogy a német leányvállalatnál a lentről felfelé irányuló megközelítés is erős. Bár a gyárigazgatók a globális lean központokból kapnak tanácsokat és ötleteket, a végső döntéseket mégis maguknak kell meghozniuk, és ezek a döntések a helyi aspirációkat is figyelembe veszik.

A lean menedzsment elméletében a vezetöi elkötelezettségről és bevonásról, mint a bevezetés fontos sikertényezőiröl beszélünk (Womack - Jones, 2003). A német eset jó példával szolgál erre. A másik két esetben a lean szakértők vannak a (lean) szervezeti struktúra középpontjában. Ezekben a leányvállalatokban a gyárigazgatók lehetnek ugyan érintettek, de nem feltétlenül követik a lean szakértők ötleteit. Összességében a felső vezetés munkájában is kevésbé szervesen jelenik meg a lean rendszer, vagy az azzal kapcsolatos információmegosztás. E téren is elmozdulás látható a dán leányvállalat gyakorlatában, amely a lean coachingon keresztül igyekszik a felsővezetői döntésekbe rutinszerüen beépíteni a lean termelési rendszer megoldásait. Ez azonban 
egy többéves folyamat. Összességében tehát a lean bevezetése elképzelhető a felső vezetés aktív részvétele nélkül, de csak korlátozott tartalommal, egy-egy területet kiragadva és nehezen fenntarthatóan mehet végbe. Egy gyáregységben a lean kultúra, amikor a mindennapi rutinokba beépül a lean munkaszervezés, csak a felső vezetés aktív és folyamatos részvételével képzelhető el.

A felső vezetők és a szakértők közötti szoros kapcsolatot Kotsova (1999) is fontosnak tartotta, amikor a stratégiai szervezeti gyakorlatok szervezetek közötti átadását vizsgálta. Ezért e kapcsolatra megalkotta a transzferkoalíció (Kotsova, 1999) fogalmát. A transzferkoalíció általában két csoportot foglal magában. A stabil mag azon kulcsvezetőket öleli fel, akik a fogadó egységnél felelösek a transzferért, és akik az elköteleződés mértékéről döntenek. A szakértői csoportban az adott gyakorlat szakértői kapnak helyet. Az esettanulmányok alapján egyértelmú, hogy a tudásmegosztási módszerek jól használhatók a transzferkoalíció erösítésére. Ehhez azonban a szakértők mély bevonását szolgáló mechanizmusok mellett kiemelten kell kezelni a helyi felső vezetés bekapcsolását is.

A tacit tudásátadás a legtöbbször igény alapján zajlik, ami rámutat a folyamatban a motiváció jelentőségére.
Bár a három esetvállalat a lean tudásátadás nagyon eltérő szervezeti hátterével rendelkezik, mindegyik sikeresnek tekinthető saját vállalatcsoportjában, ha a lean alkalmazását nézzük. Ugyanakkor mindhárom cég multinacionális (belsö) hálózatában előfordulnak kevésbé sikeres vállalatok is. Mindez arra utal, hogy a globális vállalati központból érkező támogatás szükséges, de nem elégséges a sikerhez. A leányvállalatoknak maguknak kell megtalálniuk a megfelelö helyi gyakorlatokat, és ki kell fejleszteniük egy olyan tudásszintet, melynek segítségével képesek befogadni a máshonnan érkező tudást; esetleg proaktívan keresni a központi támogatás lehetőségét, vagy a más egységben felhalmozott tapasztalat átvételének módját.

A tudás átadására használt gyakorlatok nagyon változatosak a dokumentumok megosztásától az alkalmi és rendszeres találkozókon keresztül az auditálásig. Bár e gyakorlatok egyike-másika hatékonyabb lehet a tudás megosztása szempontjából, a kevésbé hatékony gyakorlatokra mégis szükség van, hogy alapul szolgáljanak a jobb gyakorlatoknak. Összességében tehát a gyakorlatok komplex, egymásra épülő és egymást támogató rendszere a siker biztosítéka. (2. táblázat)

\section{Az esetvállalatoknál azonosított lean tudásátadási gyakorlatok}

2. táblázat

\begin{tabular}{|c|c|c|c|c|c|c|}
\hline $\begin{array}{l}\text { Tudás } \\
\text { típusa }\end{array}$ & Gyakorlat & Rövid leírás & Német & Mexikói & Dán & Gyakoriság \\
\hline \multirow[t]{12}{*}{ Explicit } & Kézikönyv & Eszközök, alapelvek leírása & $\mathrm{x}$ & $\mathrm{x}$ & $\mathrm{x}$ & $\begin{array}{l}\text { Mindig } \\
\text { elérhető }\end{array}$ \\
\hline & Projektleírások & Befejezett projektek értékeléssel & $\mathrm{x}$ & $\mathrm{x}$ & $\mathrm{x}$ & $\begin{array}{l}\text { Mindig } \\
\text { elérhetó }\end{array}$ \\
\hline & $\begin{array}{l}\text { Lean eszköz szakértő } \\
\text { (esetleg online tréningek) }\end{array}$ & $\begin{array}{l}\text { Adott lean eszköz tanítása a belső } \\
\text { hálózatban }\end{array}$ & $\mathrm{x}$ & & $\mathrm{X}$ & Igény szerint \\
\hline & Videomegbeszélés & LSz-knek & & $\mathrm{x}$ & $\mathrm{x}$ & Rendszeres \\
\hline & Globális lean konferencia & GyI, előadások és lean díjak & $\mathrm{x}$ & & & Rendszeres \\
\hline & Termelési konferencia & GyI, általános, gyárlátogatással & $\mathrm{x}$ & & $\mathrm{x}$ & Rendszeres \\
\hline & LSz találkozó & & $\mathrm{x}$ & $\mathrm{x}$ & $\mathrm{x}$ & Rendszeres \\
\hline & GyI találkozó & $\begin{array}{l}\text { Megbeszélés, egyeztetés, } \\
\text { ahol a lean is előkerül }\end{array}$ & $\mathrm{x}$ & & & Rendszeres \\
\hline & Audit & Gyári szinten & $\begin{array}{l}\text { Más leány } \\
\text { által + ÖÉ }\end{array}$ & $\begin{array}{c}\text { ÖÉ, de } \\
\text { ellenőrzött }\end{array}$ & ÖÉ & Rendszeres \\
\hline & Benchmarking & LSz, GyI, O & LSz, GyI, O & $\begin{array}{l}\text { LSz (korlá- } \\
\text { tozott) }\end{array}$ & $\mathrm{LSz}$ & Rendszeres \\
\hline & Üzemi lean projekt & Több gyár LSz együtt végzik & & & $\mathrm{x}$ & Rendszeres \\
\hline & Mintaprojekt & $\begin{array}{l}\text { Legjobb gyakorlat kialakítása a } \\
\text { globális lean központ segítségével }\end{array}$ & $\mathrm{x}$ & & & Igény szerint \\
\hline Tacit & $\begin{array}{l}\text { Junior menedzsment- } \\
\text { program }\end{array}$ & $\begin{array}{l}\text { Lean csoportot is felölelheti a } \\
\text { program }\end{array}$ & $\mathrm{x}$ & & & Igény szerint \\
\hline
\end{tabular}

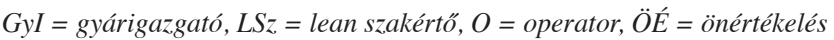




\section{Következtetések és korlátok}

A vállalatok egyelöre még küszködnek a lean termelés alkalmazásával. A kutatók érdeklődésének középpontjában föként a gyári szint áll. Nagyon kevés kutatás van, ami elemzi, hogyan támogatják a multinacionális vállalati központok a leányvállalatokat a lean alkalmazásában, bár a gyakorlati példákból jól ismert, hogy a vállalati központok gyakran építenek rendszereket a tudás és a legjobb gyakorlatok leányvállalatok közötti megosztására. Kutatásunk új iránnyal bővítette a hazai szakirodalom empirikus kutatásait is (Fehér, 2005; 2007; Gaál et al., 2009; Fejes, 2015).

Feltáró kutatásunk legfőbb hozadéka, hogy három esetvállalatnál leírjuk a lean tudásátadás eszközeit. Bemutatjuk a vállalati központok feladatait és fontosságát. Az esetvállalatok tapasztalatai arra utalnak, hogy számos szükséges, de nem elégséges feltétele van a sikeres lean adaptálásnak. A gyárigazgató mint a transzferkoalíció kulcstagja döntő szerepet játszik a tudásátadási folyamatban, illetve a lean szemlélet elmélyítésében, az elköteleződés megteremtésében. Azt is megállapíthatjuk, hogy bár ma már a lean menedzsment messze túlmutat a lean eszközök gyüjteményén, a lean utazás elején azonban még elengedhetetlen az alapeszközök elsajátítása, hogy legyen egy közös alap, amire építeni lehet. A helyi abszorpciós kapacitás építésében a központi orientációnak kulcsszerepe lehet. Véleményünk szerint az elmúlt egy évtizedben felerösödött lean termelésirendszer-adaptálási hullámban már elég sok tapasztalat halmozódott fel, hogy a sikeres bevezetés mérföldköveit, a kritikus sikertényezőket és a kapcsolódó szervezeti megoldásokat szintetizálni lehessen. A lean adaptálási ajánlásokban mindenképpen ki lehetne arra térni, hogy itt sokszor nem lineáris fejlődésről van szó.

Cikkünk fontos hiányossága, hogy csak a leányvállalatok közötti, illetve a leányvállalatok és globális központok közötti tudásátadási gyakorlatokkal foglalkozik, de nem vizsgálja, hogy a megszerzett tudást a leányvállalatok hogyan formálják saját képükre (internalizálják), és aknázzák ki. Ezért nem állíthatjuk, hogy a tudásátadás egyik vagy másik módja jobb, hiszen nem mértük a tudásátadási folyamat hatékonyságát és eredményességét. Így azt sem tudjuk, hogy a tudásátadás milyen mértékben járult hozzá az esetvállalatok sikeréhez. Mindazonáltal a hozzájárulás implicit módon létezik, mivel az interjúalanyok valószínúleg olyan gyakorlatokról beszéltek, amelyeknek van/volt hatása saját működésükre.

Nem foglalkoztunk azzal sem, hogy milyen más, külső forrásokból tudnak még profitálni a leányvállalatok, holott a lean konferenciákon megjelenő és a hasonló környezeti tényezőkkel rendelkező helyi vállalatokkal való tudásmegosztás ugyancsak jelentősen hozzájárulhat a lean fejlesztések sikeréhez, és ezt esetenként az interjúalanyok is szóba hozták.

Végezetül, fontos korlátja a cikknek az esetek alacsony száma. Szeretnénk a jövőben még további esettanulmányokat készíteni, és miután megtaláljuk a tudásátadási gyakorlatok minél teljesebb körét, kérdőívet készíteni, hogy robusztusabb eredményeket kapjunk. Azért is szükséges ez a lépés, mert az eddigi tapasztalatok alapján a lean elmélyítését a termékek, illetve a termelési folyamat jellemzői is befolyásolhatják.

\section{Lábjegyzet}

* Köszönetnyilvánítás: A tanulmány az üzemszerepek hatása a tudásmegosztásra termelési és ellátási hálózatokban" (OTKA K-112745) c. kutatási program támogatásával készült.

\section{Felhasznált irodalom}

Argote, L. (2012): Organizational learning: creating, retaining and transferring knowledge. Heidelberg: Springer

Argote, L. - Miron-Spektor, E. (2011): Organizational learning: from experience to knowledge. Organization Science, 22 (5), p. 1123-1137. (DOI: 10.1287/ orsc.1100.0621)

Boyle, T. A. - Scherrer-Rathje, M. - Stuart, I. (2011): Learning to be lean: the influence of external information sources in lean improvements. Journal of Manufacturing Technology Management, 22 (5), p. 587-603. (DOI: 10.1108/17410381111134455)

Cohen, W. M. - Levinthal, D. A. (1990): Absorptive capacity: a new perspective on learning and innovation. Administrative Science Quarterly, 35 (1), p. 128-152. (DOI: 10.2307/2393553)

Dyer, J. H. - Nobeoka, K. (2000): Creating and managing a high-performance knowledge-sharing network: the Toyota case. Strategic Management Journal, 21, p. 345-367. (DOI: 10.1002/(SICI)1097-0266(200003)21:3<345::AID-SMJ96>3.0. $\mathrm{CO} ; 2-\mathrm{N})$

Ernst, D. - Kim, L. (2002): Global production networks, knowledge diffusion, and local capability formation. Research Policy, 31, p. 1417-1429. (DOI: 10.1016/S0048-7333(02)00072-0)

Fehér, P. (2005): A technológiák szerepe a tudásmenedzsment folyamatok támogatásában. Vezetéstudomány, 36 (10), p. 11-22.

Fehér, P. (2007): Tudásmenedzsmentet támogató szervezeti megoldások. Vezetéstudomány, 38 (7-8), p. 11-21.

Fejes, J. (2015): A tudásmenedzsment fejlődési szakaszainak tettenérése a magyar üzleti tanácsadás piacán. Vezetéstudomány, 46 (8), p. 24-33. 
Gaál, Z. - Szabó, L. - Obermayer-Kovács N. (2009): „Tudásmenedzsment-profil” érettség modell. Vezetéstudomány, 40 (6), p. 2-15.

Hines, P. - Holweg, M. - Rich, N. (2004): Learning to evolve - A review of contemporary lean thinking. International Journal of Operations \& Production Management, 24 (10), p. 994-1011. (DOI: 10.1108/01443570410558049)

Inkpen, A. C. (2008): Learning through alliances: General Motors and NUMMI. California Management Review, 47 (4), p. 114-136. (DOI: 10.2307/41166319)

Jensen, R. J. - Szulanski, G. (2007): Template use and the effectiveness of knowledge transfer, Management Science, 53 (11), p. 1716-1730. (DOI: 10.1287/ mnsc.1070.0740)

Kane, G. - Alavi, M. (2007): Information technology and organizational learning: an investigation of exploration and exploitation processes. Organization Science, 18 (5), p. 796-812. (DOI: 10.1287/ orsc.1070.0286)

Kostova, T. (1999): Transnational transfer of strategic organizational practices: a contextual perspective. Academy of Management Review, 24 (2), p. 308-324. (DOI: 10.5465/AMR.1999.1893938)

Kovács, Z. (2004): A korszerü termelési rendszerek sajátosságai: a hatékonyabb gyárak titka. Harvard Business Manager, 6 (4), p. 62-69.

Kovács, Z. - Rendesi, I. (2014): Lean módszerek alkalmazása Magyarországon. Vezetéstudomány, 45 (1), p. 14-23.

Kovács, Z. - Rendesi, I. (2015): A lean projektek hatása. Vezetéstudomány, 46 (2), p. 16-24.

Lapré, M. A. - van Wassenhove, L. N. (2001): Creating and transferring knowledge for productivity improvement in factories. Management Science, 47 (10), p. 1311-1325. (DOI: 10.1287/ mnsc.47.10.1311.10264)

Letmathe, P. - Schweitzer, M. - Zielenski, M. (2012): How to learn new tasks: shop floor performance effects of knowledge transfer and performance feedback. Journal of Operations Management, 30 (3), p. 221-236. (DOI: 10.1016/j.jom.2011.11.001)

MacDuffie, J. P. - Helper, S. (1997): Creating Lean Suppliers: Diffusing Lean Production Through the Supply Chain. California Management Review, 39 (4), p. 118-151. (DOI: 10.2307/41165913)
Maritan, C. A. - Brush, T. H. (2003): Heterogeneity and transferring practices: implementing flow manufacturing in multiple plants. Strategic Management Journal, 24 (10), p. 945-959. (DOI: 10.1002/smj.311)

Nonaka, I. (1991): The knowledge creating company. Harvard Business Review, Nov-Dec, p. 96-104.

Rosenkopf, L. - Almeida, P. (2003): Overcoming local search through alliances and mobility. Management Science, 49 (6), p. 751-766. (DOI: 10.1287/ mnsc.49.6.751.16026)

Sako, M. (2004): Supplier development at Honda, Nissan and Toyota: comparative case studies of organizational capability enhancement. Industrial and Corporate Change, 13 (2), p. 281-308. (DOI: 10.1093/icc/dth012)

Shah, R. - Ward, P. T. (2003): Lean manufacturing: context, practice bundles, and performance. Journal of Operations Management, 21 (2), p. 129-149. (DOI: 10.1016/S0272-6963(02)00108-0)

Scherrer-Rathje, M. - Boyle, T. A. - Deflorin, P. (2009): Lean, take two! Reflections from the second attempt at lean implementation. Business Horizon, 52 (1), p. 79-88. (DOI: 10.1016/j.bushor.2008.08.004)

Schmenner, R. W. - Swink, M. L. (1998): On theory in operations management. Journal of Operations Management, 17 (1), p. 97-113. (DOI: 10.1016/S02726963(98)00028-X)

Secchi, R. - Camuffo, A. (2016): Rolling out lean production systems: a knowledge-based perspective. International Journal of Operations and Production Management, 36 (1), p. 61-85. (DOI: 10.1108/ IJOPM-04-2014-0194)

Staats, B. R. - Brunner, D. J. - Upton, D. M. (2011): Lean principles, learning and knowledge work: evidence from a software service provider. Journal of Operations Management, 29 (5), p. 376-390. (DOI: 10.1016/j.jom.2010.11.005)

Vereecke, A. - Dierdonck, R. - De Meyer, A. (2006): A Typology of Plants in Global Manufacturing Networks. Management Science, 52 (11), p. 1737-1750 (DOI: $10.1287 / \mathrm{mnsc} .1060 .0582)$

Womack, J. P. - Jones, D. T. (2003): Lean thinking: banish waste and create wealth in your corporation. New York: Simon \& Schuster, Inc.

Yin, R. K. (2003): Case Study Research: Design and Methods. Newbury Park, CA.:

Sage Publications 